\title{
Spontaneous Withdrawal from the Triazolobenzodiazepine Alprazolam Increases Cortical Corticotropin-Releasing Factor mRNA Expression
}

\author{
Kelly H. Skelton, Charles B. Nemeroff, and Michael J. Owens \\ Laboratory of Neuropsychopharmacology, Department of Psychiatry and Behavioral Sciences, Emory University School of Medicine, Atlanta, Georgia 30322
}

Corticotropin-releasing factor (CRF) is the major physiologic regulator of the hypothalamic-pituitary-adrenal (HPA) axis and plays a key role in coordinating the mammalian stress response. Substantial data implicates hyperactivity of CRF neuronal systems in the pathophysiology of depression and anxiety disorders. Enhanced CRF expression, release, and function have also been demonstrated during acute withdrawal from several drugs of abuse.

Previous studies revealed that chronic administration of the anxiolytic alprazolam reduced indices of CRF and $\mathrm{CRF}_{1}$ receptor function. Conversely, measures of urocortin I and $\mathrm{CRF}_{2}$ receptor function were increased. To further scrutinize these findings, we sought to determine whether CRF neuronal systems are activated during spontaneous withdrawal from the triazolobenzodiazepine alprazolam in dependent rats and to characterize the time course, extent, and regional specificity of the patterns of activation. After $14 \mathrm{~d}$ of alprazolam administration $\left(90 \mathrm{mg} \cdot \mathrm{kg}^{-1} \cdot \mathrm{d}^{-1}\right)$, spontaneous withdrawal produced activation of the HPA axis, as well as suppression of food intake and weight loss that peaked 24-48 hr after withdrawal. Remarkably, CRF mRNA expression in the cerebral cortex was markedly $(>300 \%)$ increased over the same time period. Other indices of CRF-CRF ${ }_{1}$ and urocortin $\mathrm{I}_{-} \mathrm{CRF}_{2 \mathrm{~A}}$ function, altered by chronic alprazolam treatment as previously described, returned to pretreatment levels over $96 \mathrm{hr}$. The physiologic significance of this dramatic induction of cortical CRF mRNA expression, as well as whether this occurs during withdrawal from other drugs of abuse is yet to be determined. The marked increase in CRFergic neurotransmission is hypothesized to play a major role in benzodiazepine withdrawal.

Key words: anxiety; anxiolytic; benzodiazepines; cortex; corticotropin-releasing factor; stress

\section{Introduction}

Corticotropin-releasing factor (CRF), a 41 amino acidcontaining peptide, is the major physiological regulator of the hypothalamic-pituitary-adrenal (HPA) axis. Substantial evidence has accumulated to support the hypothesis that in extrahypothalamic limbic structures and brainstem nuclei, CRF additionally functions as a neurotransmitter and serves to mediate the behavioral and autonomic components of the stress response. In addition to this key physiologic role, there is considerable evidence implicating CRF hypersecretion in the pathophysiology of depression and anxiety disorders (Owens and Nemeroff, 1991).

The effects of CRF and the related peptide urocortin I are medicated by two CRF receptor subtypes with unique anatomical localization and physiological function. In rats, the $\mathrm{CRF}_{1}$ receptor is abundant in the pituitary, cerebellum, and neocortex, and is the predominant subtype involved in coordinating the mammalian stress response, as well as mediating the anxiogenic effects of CRF. In contrast, the $\mathrm{CRF}_{2 \mathrm{~A}}$ receptor is more prevalent in subcortical regions of the CNS (Smagin and Dunn, 2000; Muller et

Received May 6, 2004; revised Sept. 5, 2004; accepted Sept. 9, 2004.

This work was supported by National Institutes of Health Grants MH42088, P50 MH58922, and U19 MH069056. Correspondence should be addressed to Dr. Michael J. Owens, Department of Psychiatry and Behavioral Sciences, Emory University School of Medicine, 1639 Pierce Drive, Suite 4000, Atlanta, GA 30322. E-mail: mowens@emory.edu. DOI:10.1523/JNEUROSCI.1737-04.2004

Copyright $\odot 2004$ Society for Neuroscience $\quad 0270-6474 / 04 / 249303-10 \$ 15.00 / 0$ al., 2003). The functional role of this latter receptor system is relatively obscure, but has been implicated in appetitive, osmoregulative, and stress-coping behaviors (Spina et al., 1996; Smagin et al., 1998; Bale et al., 2000, 2003; Kishimoto et al., 2000; Reul and Holsboer, 2002). Based on affinity and overlapping neuroanatomical distribution of urocortin I fibers and $\mathrm{CRF}_{2}$ receptor fields, the urocortin-related peptides appear to be the preferred ligand for the $\mathrm{CRF}_{2 \mathrm{~A}}$ receptor (Skelton et al., 2000a; Lewis et al., 2001; Reyes et al., 2001; Li et al., 2002).

Benzodiazepines, known to potentiate GABA-mediated $\mathrm{Cl}^{-}$ current, are clinically effective anti-anxiety agents. They have been demonstrated to exert a number of effects opposite to those of CRF, including suppression of HPA axis activation (Krulik and Cerny, 1971; Kalogeras et al., 1990; Rohrer et al., 1994, Cowley et al., 1995), as well as to directly antagonize stress-induced CRF transcription and release (Imaki et al., 1995; Pich et al., 1995), and the anxiogenic effects of centrally administered CRF (Britton et al., 1985; Swerdlow et al., 1986; Dunn and File, 1987). Our laboratory has previously shown that chronic treatment with the triazolobenzodiazepine alprazolam in the Sprague Dawley rat produced diametrically opposite effects on the $\mathrm{CRF}_{-} \mathrm{CRF}_{1}$ versus urocortin $\mathrm{I}_{-} \mathrm{CRF}_{2}$ receptor systems. Indices of $\mathrm{CRF}-\mathrm{CRF}_{1}$ functioning are decreased, and indices of urocortin $\mathrm{I}_{-} \mathrm{CRF}_{2}$ functioning are increased by chronic alprazolam treatment (Skelton et al., $2000 \mathrm{~b})$. These results support the hypothesis that the anxiolytic 
efficacy of alprazolam, and other benzodiazepines, may be mediated, at least in part, by their ability to reduce function of CRF$\mathrm{CRF}_{1}$ receptor systems that mediate the stress response and the expression of anxiety, while increasing function of urocortin $\mathrm{I}_{-} \mathrm{CRF}_{2}$ receptor systems, posited to be involved in stress coping responses.

Although benzodiazepines are anxiolytic after acute administration, they are often chronically administered to patients, producing a state of physiological dependence (Ballenger, 1991; Romach et al., 1992). Although much safer than barbiturates, when chronic benzodiazepine usage is abruptly discontinued, a withdrawal syndrome consisting of a variety of adverse physiological and behavioral reactions ensues. The anxiety, HPA axis activation, and autonomic activation that characterize the benzodiazepine withdrawal syndrome strongly resemble the mammalian stress response, suggesting the involvement of central CRF systems (Owens et al., 1991; Miller, 1997). In fact, the acute phase of withdrawal from several drugs (cannabis, cocaine, ethanol, morphine) that produce dependence is associated with evidence of increased CNS CRF neuronal activity, including HPA axis activation (Keith et al., 1983; Roberts et al., 1992; Milanes et al., 1998), increased CRF mRNA transcription and/or peptide release within the amygdala (Pich et al., 1995; Rodriguez de Fonseca et al., 1997; Richter and Weiss, 1999; Maj et al., 2003; Zhou et al., 2003), and/or increased CRF concentrations in the CSF (Adinoff et al., 1996). We have previously reported increased HPA axis activity after withdrawal from benzodiazepines (Owens et al., 1991). In this study we sought to confirm and expand on our previous findings to determine whether CRF neuronal systems are activated during spontaneous withdrawal from alprazolam in dependent rats, as well as to examine the time course and neuroanatomical patterns of activation.

\section{Materials and Methods}

Animals. Male Sprague Dawley rats (225-250 gm on arrival; Charles River Laboratories, Raleigh, NC) were housed individually with water available ad libitum in an environmentally controlled animal facility with a $12 \mathrm{hr}$ light/dark cycle (lights on at 7:30 A.M.). The food supply consisted of a control or alprazolam-supplemented liquid diet, as described below. All animals were weighted and handled daily throughout the course of the experiment.

Drug treatment. For $14 \mathrm{~d}$, rats ( $n=6$ per group) received a liquid, fat emulsion-based diet (Bio-Serv Inc., Frenchtown, NJ) supplemented with $0.01 \%(\mathrm{w} / \mathrm{v})$ saccharin, $0.2 \%$ polyethylene glycol $(\mathrm{PEG}) 400(\mathrm{v} / \mathrm{v})$, and sufficient alprazolam to deliver an oral dose of $90 \mathrm{mg} \cdot \mathrm{kg}^{-1} \cdot \mathrm{d}^{-1}$. This dose was chosen on the basis of our previous studies (Owens et al., 1991; Skelton et al., 2000c). A control group of rats $(n=6)$ received the same diet, without alprazolam supplementation. Fresh diet was added, and intake was recorded for individual rats during each of three $8 \mathrm{hr}$ epochs daily (8:00 A.M. to 4:00 P.M., 4:00 P.M. to 12:00 A.M., 12:00 A.M. to 8:00 A.M.). The alprazolam concentration of the diet was adjusted daily, based on average rat weight and intake, to maintain the oral dose of 90 $\mathrm{mg} \cdot \mathrm{kg}^{-1} \cdot \mathrm{d}^{-1}$. On day 14 , the control and one group of alprazolamtreated rats were killed, and the remaining rats were then switched to the control diet to induce alprazolam withdrawal. Subsequently, one group of rats was killed at each of the 24, 48, and $96 \mathrm{hr}$ time points after withdrawal of alprazolam from the diet. Additional control rats were not killed at the subsequent withdrawal time points because of the large number of rats, expense, and expansion of the scope of the assays that this would involve. This does add a potential confound, in that variations in the conditions within the animal facility may impact on end point measures analyzed in this study. However, because this laboratory is actively involved in studying the effects of stress on gene expression, HPA axis activity, and behavior, every effort is made to standardize these conditions and to prevent unexpected variance.

All rats were killed by means of decapitation, between the hours of 9:00 and 10:30 A.M. After decapitation, trunk blood was collected for adrenocorticotropic hormone (ACTH) and corticosterone assay as described previously (Skelton et al., 2000b). Brains and anterior pituitaries were rapidly removed, frozen on dry ice, and stored at $-80^{\circ} \mathrm{C}$ until cryostat sectioning or assay.

ACTH and corticosterone radioimmunoassay analysis. ACTH was measured in duplicate plasma samples by a two-site immunoradiometric assay (Nichols Diagnostics, San Juan Capistrano, CA) with a coefficient of variation of $5 \%$ and sensitivity (blank $\pm 2 \mathrm{SD}$ ) of $1 \mathrm{pg} / \mathrm{ml}$. Corticosterone was assayed in duplicate samples of rat serum by a double antibody RIA (ICN Biochemicals, Costa Mesa, CA) with a coefficient of variation of $6 \%$ and sensitivity (blank $\pm 2 \mathrm{SD}$ ) of $1.2 \mathrm{ng} / \mathrm{ml}$.

In situ hybridization. Serial coronal brain sections $(20 \mu \mathrm{m})$ were sliced on a cryostat at $-17^{\circ} \mathrm{C}$, thaw mounted onto SuperFrost Plus slides (Fisher Scientific, Pittsburgh, PA) under RNase-free conditions, and stored with Humi-Cap desiccant capsules (Invitrogen, Grand Island, $\mathrm{NY}$ ) at $-80^{\circ} \mathrm{C}$ until the assay. In situ hybridization was performed according to the procedures described by Simmons et al. (1989) with minor modifications as described in detail in Skelton et al. (2000b).

After in situ hybridization, the slides were delipidated in xylene and briefly dipped in Eastman Kodak (Rochester, NY) NTB-2 emulsion at $42^{\circ} \mathrm{C}$, and dried for $2-3 \mathrm{hr}$. The slides were then stored in a sealed and foil-wrapped box in the dark at $4^{\circ} \mathrm{C}$ for approximately three times longer than the exposure used to achieve a strong signal on film. Slides were developed in Kodak D-19 developer for 4 min, dipped in double distilled water $\left(\mathrm{ddH}_{2} 0\right)$ for $10 \mathrm{sec}$, transferred to Kodak fixer for $5 \mathrm{~min}$, and rinsed in $\mathrm{ddH}_{2} \mathrm{O}$ for $30 \mathrm{~min}$. Immediately after developing, slides were stained in hematoxylin for $1 \mathrm{~min}$, dehydrated through an ethanol series, and coverslipped with distyrene-plasticiser-xylene. For comparison, adjacent sections of fresh-frozen tissue were fixed in $4 \%$ paraformaldehyde for 30 min and similarly stained.

CRF receptor autoradiography. After a modification of the techniques of De Souza et al. (1985) and Primus et al. (1997), ex vivo CRF receptor autoradiography was performed on $20 \mu \mathrm{m}$ rat brain sections mounted on SuperFrost Plus slides (Fisher Scientific) and stored with Humi-Cap desiccant capsules (Invitrogen, Gaithersburg, MD) at $-80^{\circ} \mathrm{C}$ until assay. Brain sections were fixed for $2 \mathrm{~min}$ in $0.1 \%$ paraformaldehyde followed by a $15 \mathrm{~min}$ incubation in assay buffer $\left[50 \mathrm{mmol} / 1\right.$ Tris, $10 \mathrm{mmol} / 1 \mathrm{MgCl}_{2}$, $2 \mathrm{mmol} / \mathrm{l}$ EGTA, $0.1 \%$ bovine serum albumin (BSA), $0.1 \mathrm{mmol} / \mathrm{l}$ bacitracin, and $0.1 \%$ aprotinin, $\mathrm{pH} 7.5$ ] to remove endogenous CRF. Next, triplicate slides containing adjacent brain sections were incubated for 2 $\mathrm{hr}$ at room temperature in one of three conditions: (1) $0.1 \mathrm{nmol} / \mathrm{l} \mathrm{radio-}$ labeled $\left[{ }^{125} \mathrm{I}\right]$-sauvagine (DuPont NEN, Boston, MA) to determine total binding at both the $\mathrm{CRF}_{1}\left(K_{\mathrm{i}}=1.6 \mathrm{nM}\right)$ and $\mathrm{CRF}_{2}$ receptor subtypes $\left(K_{\mathrm{i}}=5.2 \mathrm{nM}\right),(2) 0.1 \mathrm{nmol} / 1$ radiolabeled $\left[{ }^{125} \mathrm{I}\right]$-sauvagine $+1 \mu \mathrm{mol} / 1$ CP-154,526 $\left(\mathrm{CRF}_{1}\right.$-specific antagonist; $K_{\mathrm{i}}=2.7 \mathrm{~nm}$ for $\mathrm{CRF}_{1} ; K_{\mathrm{i}}=>10$ $\mu \mathrm{M}$ for $\mathrm{CRF}_{2}$ ) to determine $\mathrm{CRF}_{2}$ receptor-specific binding, or (3) 0.1 nmol/l radiolabeled $\left[{ }^{125} \mathrm{I}\right.$ ]-sauvagine $+1 \mu \mathrm{mol} / \mathrm{l}$ unlabeled sauvagine (American Peptide Company Inc., Sunnyvale, CA) to determine nonspecific binding. After the incubation, unbound radioligand was removed by two 5 min rinses in ice-cold $\left(4^{\circ} \mathrm{C}\right)$ PBS plus $1 \%$ BSA on a rotating platform at $60 \mathrm{rpm}$, followed by two brief dips in ice-cold dd $\mathrm{H}_{2} \mathrm{O}$. Slides were then rapidly dried with a blow dryer on the coldest setting and apposed to Kodak Biomax MR film with $\left[{ }^{125} \mathrm{I}\right]$-microscale standards (Amersham Biosciences, Arlington Heights, IL) for 80-90 hr.

Image analysis. Images on film from the in situ hybridization and receptor autoradiography films were digitized with a Dage-MTI (Michigan City, IN) CCD-72 image analysis system equipped with a Nikon camera using MCID (Imaging Research) software. Optical densities were calibrated against $\left[{ }^{14} \mathrm{C}\right]$ standards for in situ hybridization or $\left[{ }^{125} \mathrm{I}\right]$ microscale standards for receptor autoradiography and expressed in terms of nanocuries per gram of tissue equivalent. Messenger RNA levels were calculated for distinct neuroanatomical regions in each brain slice by subtracting the neutral background density from the specific signal. CRF receptor density was calculated for distinct neuroanatomical regions as follows: $\mathrm{CRF}_{1}$ receptor-specific binding was calculated as "total binding $-\mathrm{CRF}_{2 \mathrm{~A}}$ receptor binding," and $\mathrm{CRF}_{2 \mathrm{~A}}$ receptor-specific binding was calculated as " $\mathrm{CRF}_{2 \mathrm{~A}}$ receptor binding - nonspecific binding." In all cases, two to six sections per region were matched for rostrocaudal 

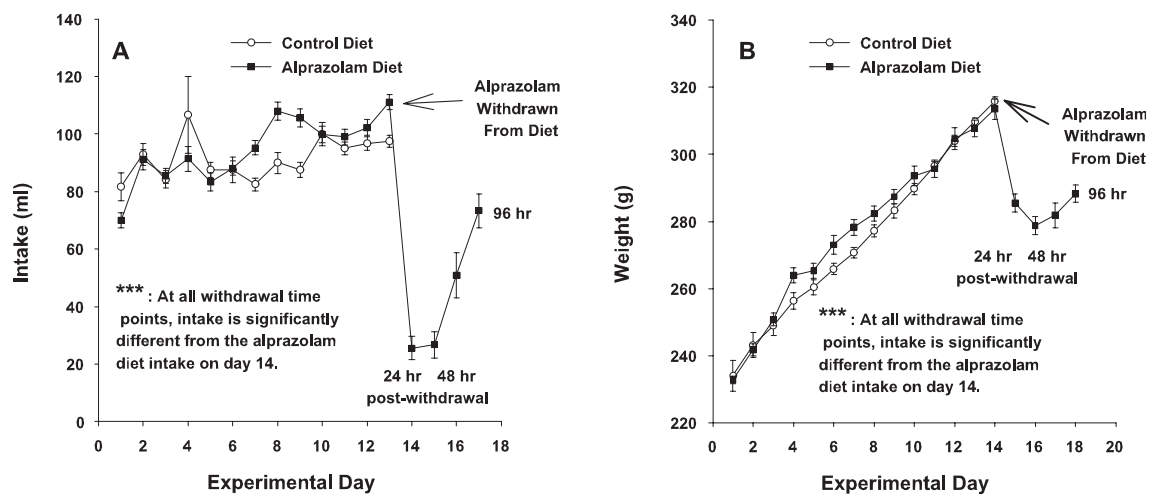

Figure 1. Food intake and body weight are decreased after spontaneous withdrawal from alprazolam. $A$, Daily intake (in milliliters) and body weight $(B)$ were recorded during each $24 \mathrm{hr}$ period in male Sprague Dawley rats maintained on a control liquid diet, an alprazolam-supplemented diet at a dose of $90 \mathrm{mg} \cdot \mathrm{kg}^{-1} \cdot \mathrm{d}^{-1}$ and 24, 48, 72, or $96 \mathrm{hr}$ after withdrawal of alprazolam from the diet. Each bar represents mean \pm SEM; $n=6$ for the control group, $n=24$ for the alprazolam-treated group on days $1-14, n=18$ for the $24 \mathrm{hr}$ withdrawal group, $n=12$ for the $48 \mathrm{hr}$ withdrawal group, and $n=6$ for the 72 and $96 \mathrm{hr}$ withdrawal groups. ${ }^{* *} p<0.001$ versus chronic alprazolam group on day 14 of diet by one-way ANOVA followed by StudentNewman-Keuls post hoc pairwise analysis.

level according to the atlas of Paxinos and Watson (1986) and quantified and averaged to produce a single value for each animal.

CRF receptor binding in tissue homogenates. Single point CRF receptor binding assays were performed on anterior pituitaries, stored at $-80^{\circ} \mathrm{C}$ until the time of assay. To remove bound endogenous CRF, the pituitaries were homogenized in $2 \mathrm{ml}$ of incubation buffer $(50 \mathrm{mmol} / \mathrm{l}$ Tris, 10 $\mathrm{mmol} / \mathrm{l} \mathrm{MgCl}_{2}, 2 \mathrm{mmol} / \mathrm{l} \mathrm{EGTA}$, and 0.1\% BSA, pH 7.2) at room temperature, using a Brinkmann Instruments (Westbury, NY) Polytron model 3100 at 20,000 rpm for $10 \mathrm{sec}$, followed by centrifugation at 17,000 $\mathrm{rpm}$ for $10 \mathrm{~min}$ at $4^{\circ} \mathrm{C}$. After two repetitions of this step, the pellets were resuspended and homogenized in $1.5 \mathrm{ml}$ of the above buffer supplemented with $10 \mu \mathrm{g} / \mathrm{ml}$ aprotinin and $0.1 \mathrm{mmol} / \mathrm{l}$ bacitracin. Triplicate $100 \mu \mathrm{l}$ aliquots of membrane homogenate were incubated for $2 \mathrm{hr}$ at room temperature with $50 \mu \mathrm{l}\left[{ }^{125} \mathrm{I}\right]$ ovine $\mathrm{CRF}(0.1 \mathrm{nmol} / \mathrm{l}$ final concentration; New England Nuclear), a $50 \mu \mathrm{l}$ isotopic dilution of unlabeled ovine CRF ( $0.9 \mathrm{nmol} / \mathrm{l}$ final concentration), and $100 \mu \mathrm{l}$ of either incubation buffer (to determine total binding) or unlabeled rat CRF ( $1 \mu \mathrm{mol} / \mathrm{l}$ final concentration; to determine nonspecific binding). After incubation, samples were microcentrifuged for $3 \mathrm{~min}$ at $13,000 \mathrm{rpm}$ at $4^{\circ} \mathrm{C}$, aspirated, then washed in ice-cold $10 \mathrm{mmol} / \mathrm{l}$ PBS containing $0.01 \%$ Triton $\mathrm{X}-100$, $\mathrm{pH}$ 7.4. After a second microcentrifugation and aspiration, the pellet was counted in an LKB-Wallac (Gaithersburg, MD) gamma counter $(86 \%$ efficiency).

Additional aliquots of tissue homogenate were microcentrifuged at $13,000 \mathrm{rpm}$ for $3 \mathrm{~min}$, aspirated, and resuspended in $1 \mathrm{ml}$ of $1 \mathrm{M} \mathrm{NaOH}$. Total protein content was then determined using the method of Lowry et al. (1951) with BSA as the standard.

Specific CRF receptor binding was calculated by subtracting the mean counts per minute in the triplicate nonspecific binding condition from the mean counts per minute in the triplicate total binding condition. Counts per minute bound was then converted to femtomoles bound and normalized to protein content to produce a specific binding number expressed as femtomoles of CRF bound per milligram of protein. Specific binding as a percentage of total binding varies slightly among brain regions, but generally represents $\sim 60-70 \%$ of total binding. The $K_{\mathrm{d}}$ of $\left[{ }^{125} \mathrm{I}\right]$ ovine CRF binding in our laboratory ranges from $0.25-0.6 \mathrm{nmol} / \mathrm{l}$.

Drugs. Alprazolam was a gift from Upjohn (Kalamazoo, MI).

Statistics. Comparisons within the alprazolam withdrawal time course ( $t=0,24,48$, and $96 \mathrm{hr}$ after withdrawal) were performed using one-way ANOVA with Student-Newman-Keuls pairwise testing for post hoc analysis following ANOVA. The control group could not be directly compared with the alprazolam withdrawal time course groups within the same one-way ANOVA, because it differed with respect to two factors (drug exposure and time of killing). Therefore, all comparisons between control and chronic alprazolam-treated rats were performed by means of a two-tailed $t$ test. The " 0 " withdrawal time point was used for determining the effects of chronic alprazolam treatment in comparison with control rats. The above statistical comparisons were made using the raw data, i.e., the absolute levels of mRNA expression or receptor binding from autoradiographic analysis. To allow the reader to more readily discern the degree of change produced by chronic alprazolam treatment and then to compare the alterations in gene expression-receptor binding that occur during the withdrawal time course, the data are presented relative to percentage of control values in the figures that follow. Furthermore, expressing the data as percentage of control allows for the presentation of data for several different neuroanatomical regions, which may differ greatly in the absolute level of mRNA expression or receptor binding, in the same graph, with a linear and nonbroken $y$-axis.

In addition, a linear regression model was used to assess for correlations between ACTH and corticosterone concentrations and the resultant anterior pituitary $\mathrm{CRF}_{1}$ receptor binding within the alprazolam withdrawal time course. All data are expressed as the mean \pm SEM.

\section{Results \\ Dietary intake and rat weight during chronic alprazolam administration and spontaneous withdrawal}

Rats maintained on both the control and alprazolamsupplemented diets were well matched in daily intake and weight gain over the course of the first $14 \mathrm{~d}$ of the experiment. After removal of alprazolam from the diet of dependent rats, there was a precipitous decline in dietary intake $(\sim 80 \%)$ which persisted until $48 \mathrm{hr}$ after withdrawal (Fig. $1 A$ ). Thereafter intake began to steadily increase, but at $96 \mathrm{hr}$ after withdrawal, remained well below the levels observed in control and chronic alprazolamtreated rats. As expected, a dramatic weight loss accompanied this decreased intake (Fig. 1B). A maximal weight loss of $35 \mathrm{gm}$, or $11.1 \%$ of body weight, was apparent $48 \mathrm{hr}$ after alprazolam withdrawal. Thereafter, this trend reversed, and weight gains were demonstrated at both the 72 and $96 \mathrm{hr}$ withdrawal time points. However, even $96 \mathrm{hr}$ after removal of alprazolam from the diet, the body weight of the alprazolam withdrawal groups remained 25 gm below that observed on day 14 of control or alprazolam diet administration.

\section{HPA axis activity during alprazolam dependence and spontaneous withdrawal}

The low basal concentrations of plasma ACTH and serum corticosterone exhibited in both the control and alprazolam-treated rats indicate that these rats were not stressed at the time of killing (Fig. 2A,B). Similar to our previous findings (Skelton et al., 2000b), chronic alprazolam treatment decreased plasma ACTH by $31.3 \%(11.8 \pm 2.6 \mathrm{vs} 8.1 \pm 4.1 \mathrm{pg} / \mathrm{ml})$ and serum corticosterone by $48.1 \%(2.7 \pm 0.6$ vs $1.4 \pm 0.3 \mathrm{ng} / \mathrm{ml})$ concentrations compared with controls rats, but these differences were not statistically significant. Spontaneous alprazolam withdrawal rapidly and markedly stimulated HPA axis activity, causing a more than sixfold increase in ACTH concentration (to $59.5 \pm 13.9 \mathrm{pg} / \mathrm{ml}$ ) and a 250-fold increase in corticosterone concentration (to $356.3 \pm 86.5 \mathrm{ng} / \mathrm{ml} ; p<0.01$ vs chronic alprazolam and $96 \mathrm{hr}$ withdrawal groups) at $24 \mathrm{hr}$ after withdrawal of alprazolam from the diet. Plasma ACTH remained elevated at $48 \mathrm{hr}$ after with- 
drawal to a similar extent $(56.6 \pm 30.0 \mathrm{pg} /$ $\mathrm{ml}$ ), whereas serum corticosterone concentrations had declined approximately halfway back to control values (160.3 \pm $95.1 \mathrm{ng} / \mathrm{ml})$. By $96 \mathrm{hr}$ after alprazolam withdrawal, both ACTH $(19.1 \pm 1.5 \mathrm{pg} /$ $\mathrm{ml})$ and corticosterone $(23.8 \pm 6.1 \mathrm{ng} / \mathrm{ml})$ concentrations had returned to baseline levels.

$\mathrm{CRF}_{1}$ receptor binding in the anterior pituitary followed a similar time course. Compared with the control rats, there was a small, but nonsignificant increase in $\mathrm{CRF}_{1}$ binding in the anterior pituitaries of the chronic alprazolam-treated rats $(100.7 \pm 10.9$ vs $113.4 \pm 12.7 \mathrm{fmol} / \mathrm{mg}$ protein) (Fig. 3). At both 24 and $48 \mathrm{hr}$ after alprazolam withdrawal, $\mathrm{CRF}_{1}$ receptor binding was significantly decreased in the anterior pituitary by $\sim 36 \%(73.1 \pm 6.5$ and $71.0 \pm 5.4 \mathrm{fmol} / \mathrm{mg}$ protein, respectively; $p<0.05$ vs chronic alprazolam and $96 \mathrm{hr}$ withdrawal groups), likely reflecting a downregulation of $\mathrm{CRF}_{1}$ receptors secondary to increased hypothalamic release of CRF driving the HPA axis response to withdrawal. This hypothesis is strengthened by the statistically significant correlation between increased corticosterone concentrations and reduced $\mathrm{CRF}_{1}$ receptor binding in the anterior pituitaries of individual rats over the alprazolam withdrawal time course $(r=-0.46 ; p=0.024)$. A similar correlation between increased ACTH concentrations and reduced anterior pituitary $\mathrm{CRF}_{1}$ receptor binding closely approached statistical significance $(r=-0.39 ; p=0.063)$. CRF ${ }_{1}$ receptor binding density returned to normal (no different from controls, $98.0 \pm 13.8$ $\mathrm{fmol} / \mathrm{mg}$ protein) by $96 \mathrm{hr}$ after alprazolam withdrawal.

\section{CRF mRNA expression}

As predicted from the HPA axis data, alprazolam treatment, by itself, did not significantly alter CRF mRNA expression in the paraventricular nucleus of the hypothalamus (PVN) (Fig. 4A) $(2251.3 \pm 176.9$ vs $2005.8 \pm 124.1 \mathrm{nCi} / \mathrm{gm})$. However, after discontinuation of alprazolam from the diet, CRF mRNA expression increased until $48 \mathrm{hr}$ after withdrawal $(3143.4 \pm 283.6 \mathrm{nCi} /$ gm; $p<0.01$ vs alprazolam), and thereafter began to decline.

Chronic administration of alprazolam produced a $18.7 \%$ decrease in CRF mRNA in the central nucleus of the amygdala (CeA) $(497.1 \pm 50.5$ vs $404.1 \pm 42.4 \mathrm{nCi} / \mathrm{gm} ; p=0.19)$, a change that is similar in direction, although smaller in magnitude than previously reported (Skelton et al., 2000b). After withdrawal of alprazolam, no consistent alterations were observed in CRF mRNA expression within this region. A similar pattern was revealed in the bed nucleus of the stria terminalis (BNST). Chronic alprazolam treatment produced a small $(17.2 \%)$ decrease in CRF mRNA expression that was just short of statistical significance $(119.3 \pm 3.2 \mathrm{vs} 98.8 \pm 9.1 \mathrm{nCi} / \mathrm{gm} ; p=0.06)$. After withdrawal of alprazolam from the diet, CRF mRNA levels were significantly increased at the $24 \mathrm{hr}(130.8 \pm 7.5 \mathrm{nCi} / \mathrm{gm} ; p<0.05$ vs alprazolam) time point only.

The most robust withdrawal-induced increase in CRF mRNA expression was demonstrated in the cerebral cortex (Fig. 4B). Although there was a slight, nonsignificant decrease of $14.6 \%$ in CRF mRNA expression in the cortex as a result of alprazolam administration $(20.1 \pm 1.6 \mathrm{nCi} / \mathrm{gm}$ vs $17.3 \pm 1.1 \mathrm{nCi} / \mathrm{gm})$, there

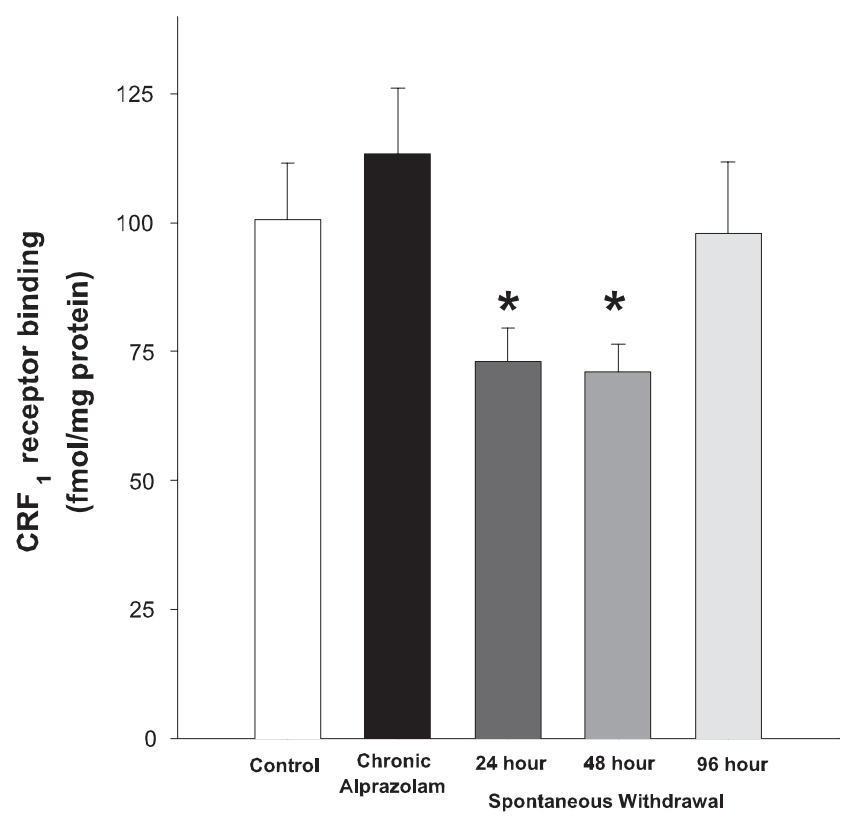

Figure 3. $\mathrm{CRF}_{1}$ receptor binding is decreased in the anterior pituitary 24 and $48 \mathrm{hr}$ after spontaneous withdrawal from alprazolam. $\mathrm{CRF}_{1}$ receptor binding was measured in homogenized anterior pituitaries of male Sprague Dawley rats after $14 \mathrm{~d}$ of a control liquid diet, an alprazolam-supplemented liquid diet at a dose of $\mathrm{mg} \cdot \mathrm{kg}^{-1} \cdot \mathrm{d}^{-1}$, and 24,48 , or $96 \mathrm{hr}$ after withdrawal of alprazolam from the diet. Each bar represents mean $\pm \mathrm{SEM} ; n=6$ per group. ${ }^{*} p<0.05$ versus chronic alprazolam and $96 \mathrm{hr}$ withdrawal groups by one-way ANOVA followed by Student-Newman-Keuls post hoc pairwise analysis.

was a dramatic increase of $>300 \%(86.0 \pm 8.5 \mathrm{nCi} / \mathrm{gm} ; p<0.001$ vs alprazolam and all other withdrawal time points) that was observed throughout the cerebral cortex (from approximately bregma level +1.0 to $-4 \mathrm{~mm}$ ) at $24 \mathrm{hr}$ after alprazolam withdrawal. This increase in cortical CRF mRNA expression rapidly declined to only $59.6 \%$ above control levels by $48 \mathrm{hr}$ after withdrawal $(33.1 \pm 4.0 \mathrm{nCi} / \mathrm{gm})$ and returned to within $10 \%$ of control values by $96 \mathrm{hr}$ after withdrawal $(21.3 \pm 1.5 \mathrm{nCi} / \mathrm{gm})$.

Hematoxylin staining of emulsion-dipped slides yielded very clear bright-field images (Fig. 4C). The background was very low in all sections examined, and the silver grains were localized in a 


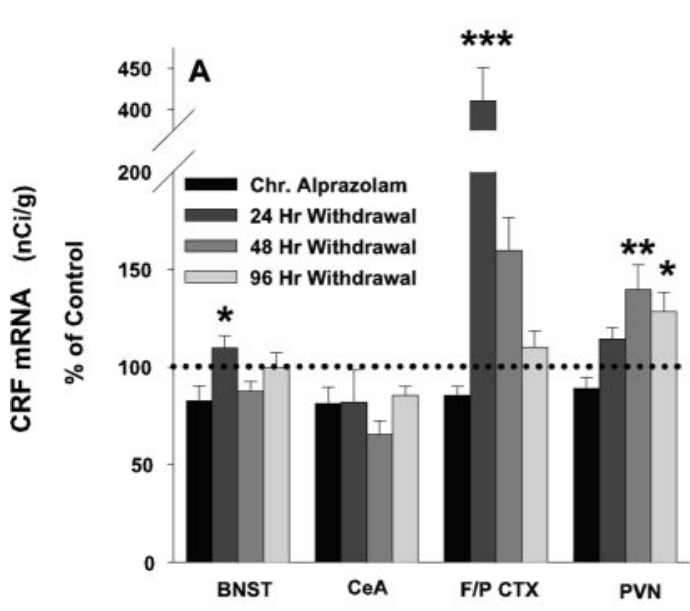

C

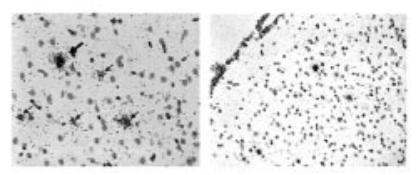

Chronic Alprazolam

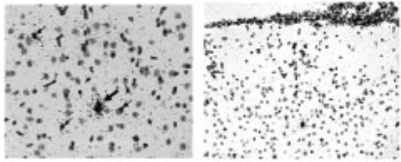

24 Hour Withdrawal
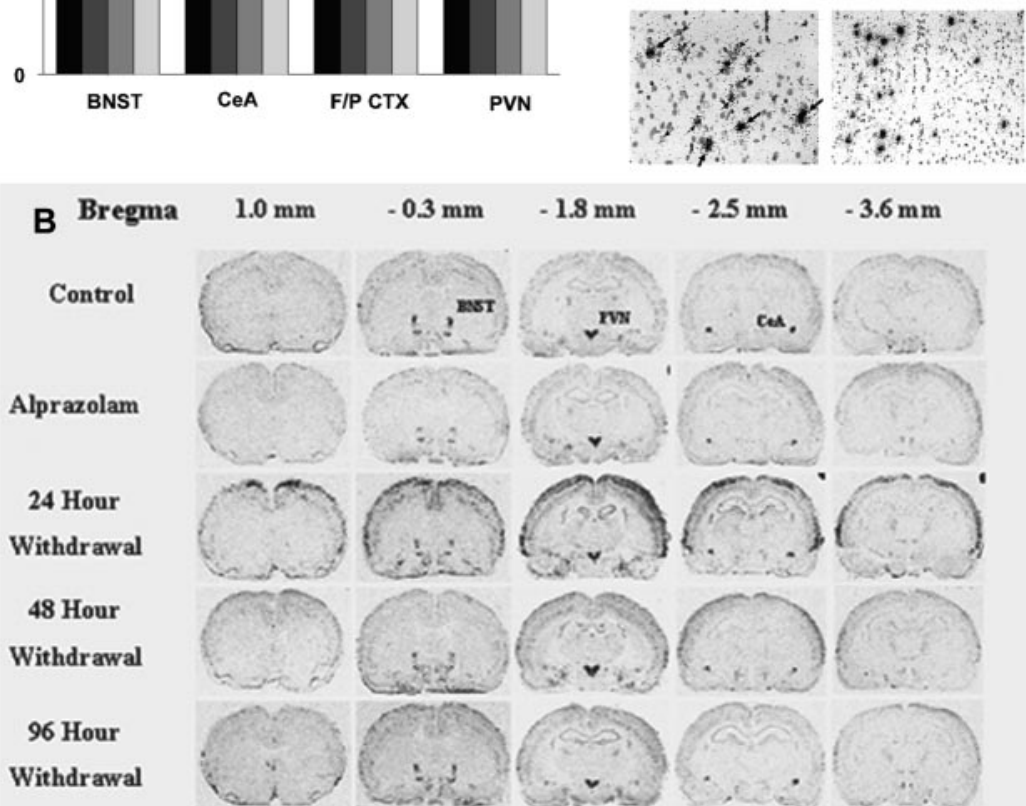

Figure 4. CRF mRNA expression is increased in the frontal-parietal cortex and the paraventricular nucleus of the hypothalamus after spontaneous alprazolam withdrawal. $A$, CRF mRNA expression was measured via densitometric analysis subsequent to in situ hybridization performed in $20 \mu \mathrm{m}$ brain slices from male Sprague Dawley rats after $14 \mathrm{~d}$ of a control liquid diet, an alprazolam-supplemented diet at a dose of $90 \mathrm{mg} \cdot \mathrm{kg}^{-1} \cdot \mathrm{d}^{-1}$, and 24,48 , or $96 \mathrm{hr}$ after withdrawal of alprazolam from the diet. Each bar represents mean $\pm \mathrm{SEM} ; n=6$ per group. Two to four slices were quantified per region, per rat. ${ }^{*} p<0.05$ versus chronic alprazolam; ${ }^{* *} p<0.01$ versus chronic alprazolam; ${ }^{* * *} p<0.001$ versus chronic alprazolam, 48 , and $96 \mathrm{hr}$ withdrawal groups by one-way ANOVA followed by Student-Newman-Keuls post hoc pairwise analysis. $B$, Representative images of CRF mRNA in the BNST, CeA, F/P CTX, and PVN after in situ hybridization. C, Representative bright-field images of CRF mRNA signal in the parietal cortex at $200 \times$ (left panel) and 100X (right panel) after in situ hybridization and emulsion dipping. Slides are counterstained with hematoxylin. The large arrows denote cells exhibiting a high level of CRF mRNA expression, and the small arrows denote cells exhibiting a lower level of CRF mRNA expression.

pattern compatible with a cellular distribution for CRF mRNA expression. In all experimental groups, CRF mRNA expression was particularly prominent in cortical layers II and III, consistent with the previously published cortical localization (Yan et al., 1998).

\section{Urocortin I mRNA expression}

As previously reported (Skelton et al., 2000b), urocortin I mRNA expression in the Edinger-Westphal nucleus (EWN) of chronic alprazolam-treated rats was more than doubled from the levels observed in control rats $(12027.0 \pm 485.2$ vs $24695.4 \pm 902.8$ $\mathrm{nCi} / \mathrm{gm} ; p<0.001$ vs controls) (Fig. 5). Thereafter, urocortin I mRNA expression demonstrated a steady decline during withdrawal, returning to levels statistically indistinguishable from controls at $96 \mathrm{hr}$ after withdrawal [22363.1 $\pm 572.5 \mathrm{nCi} / \mathrm{gm}(24$ $\mathrm{hr}) ; 20577.3 \pm 1883.8 \mathrm{nCi} / \mathrm{gm}(48 \mathrm{hr}) ; 14847.0 \pm 1125.2 \mathrm{nCi} / \mathrm{gm}$
(96 hr), $p<0.001$ vs chronic alprazolam and $24 \mathrm{hr}$ withdrawal, $p<0.01 \mathrm{vs} 48 \mathrm{hr}$ withdrawal].

\section{$\mathrm{CRF}_{1}$ receptor binding and mRNA expression}

$\mathrm{CRF}_{1}$ receptor mRNA expression was decreased in the basolateral amygdala by alprazolam treatment (Fig. 6A) (199.5 \pm 14.7 vs $125.6 \pm 13.9 \mathrm{nCi} / \mathrm{gm} ; p<0.01)$. After removal of alprazolam from the diet, $\mathrm{CRF}_{1}$ receptor mRNA expression remained similarly decreased at $24 \mathrm{hr}$, and thereafter increased toward control levels. $\mathrm{CRF}_{1}$ receptor mRNA expression in the frontal-parietal cerebral cortex followed a similar pattern, with alprazolam inducing a $19.2 \%$ decrease $(285.0 \pm 25.3$ vs $230.4 \pm$ $12.3 \mathrm{nCi} / \mathrm{gm})$ that did not achieve statistical significance. After alprazolam withdrawal, $\mathrm{CRF}_{1}$ receptor mRNA expression began to climb toward control levels. Within the cerebellum, $\mathrm{CRF}_{1}$ receptor mRNA expression was not altered by alprazolam administration or withdrawal at any time points.

The direction of alprazolam and withdrawal-induced changes in $\mathrm{CRF}_{1}$ receptor binding largely paralleled the alterations in mRNA expression described above. However, the changes were generally of a smaller magnitude. Within the basolateral amygdala, $\mathrm{CRF}_{1}$ receptor binding was decreased to $85.0 \%$ of control levels as a result of alprazolam administration $(1768.2 \pm 96.7$ vs $1502.3 \pm 101.0 \mathrm{nCi} / \mathrm{gm}$; $p=0.09$ ) and similarly decreased to $79.1 \%$ of control at $24 \mathrm{hr}$ after withdrawal (Fig. $6 B)$. Thereafter, $\mathrm{CRF}_{1}$ receptor binding returned toward control levels. None of these variations attained statistical significance. Cortical $\mathrm{CRF}_{1}$ receptor binding was likewise decreased by $13.8 \%$ after alprazolam treatment $(1383.3 \pm 26.3$ vs $1193.0 \pm$ $41.3 \mathrm{nCi} / \mathrm{gm} ; p<0.01) . \mathrm{CRF}_{1}$ receptor binding in the cortex remained similarly decreased until $96 \mathrm{hr}$ after withdrawal, at which time it began to increase toward control levels. As with the mRNA expression, $\mathrm{CRF}_{1}$ receptor binding in the cerebellum was not altered by alprazolam administration or withdrawal.

\section{$\mathrm{CRF}_{2 \mathrm{~A}}$ receptor binding and mRNA expression}

As in our previous study (Skelton et al., 2000b), $\mathrm{CRF}_{2 \mathrm{~A}}$ receptor mRNA in the lateral septum (LS) was increased by $28.8 \%$ as a result of chronic alprazolam treatment (Fig. $7 A)(121.8 \pm 3.7$ vs $157.0 \pm 12.2 \mathrm{nCi} / \mathrm{gm} ; p<0.05)$. Thereafter $\mathrm{CRF}_{2 \mathrm{~A}}$ receptor mRNA expression declined toward control levels in that region, with the decline becoming statistically significant at $48 \mathrm{hr}$ after alprazolam withdrawal $(115.6 \pm 7.1 \mathrm{nCi} / \mathrm{gm} ; p<0.05$ vs alprazolam). Within the ventromedial hypothalamus $(\mathrm{VMH})$, the level of $\mathrm{CRF}_{2 \mathrm{~A}}$ receptor mRNA expression was not altered by chronic alprazolam administration (189.7 \pm 10.3 vs $182.8 \pm 11.8$ $\mathrm{nCi} / \mathrm{gm})$. There was, however, a statistically significant increase 


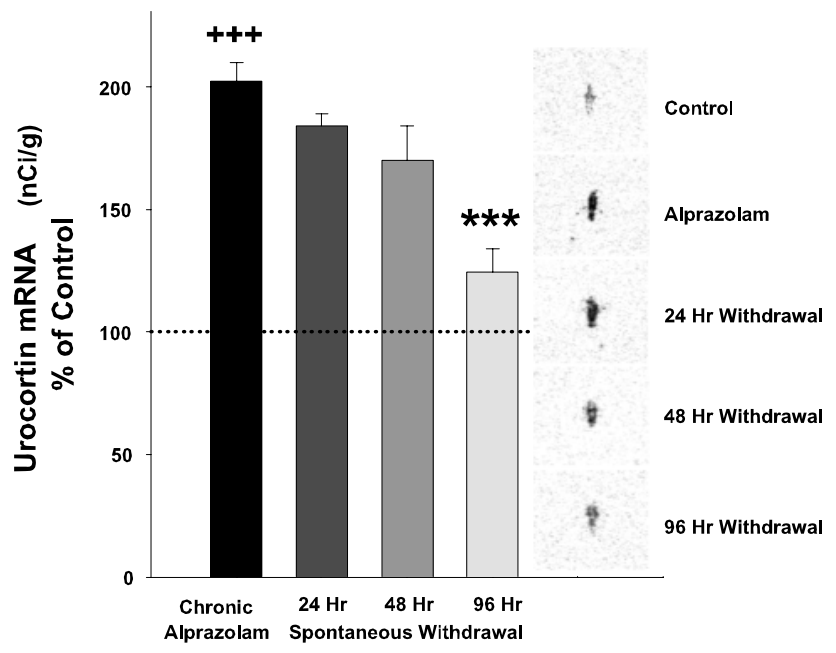

Figure 5. Urocortin mRNA expression in the Edinger-Westphal nucleus is increased by chronic alprazolam treatment and returns toward control levels by $96 \mathrm{hr}$ after spontaneous withdrawal from alprazolam. Urocortin mRNA expression was measured via densitometric analysis subsequent to in situ hybridization performed in $20 \mu \mathrm{m}$ brain slices from male Sprague Dawley rats after $14 \mathrm{~d}$ of a control liquid diet, an alprazolam-supplemented diet at a dose of 90 $\mathrm{mg} \cdot \mathrm{kg}^{-1} \cdot \mathrm{d}^{-1}$, and 24,48 , or $96 \mathrm{hr}$ after withdrawal of alprazolam from the diet. Each bar represents mean \pm SEM; $n=6$ per group. ${ }^{+++} p<0.001$ versus controls by a two-tailed $t$ test; ${ }^{* * *} p<0.001$ versus chronic alprazolam and $24 \mathrm{hr}$ withdrawal groups, and $p<0.01$ versus $48 \mathrm{hr}$ withdrawal groups by one-way ANOVA followed by Student-Newman-Keuls post hoc pairwise analysis. Representative images of Urocortin I mRNA in the Edinger-Westphal nucleus after in situ hybridization are included as an inset to the graph.

in $\mathrm{CRF}_{2 \mathrm{~A}}$ receptor mRNA expression in the $\mathrm{VMH} 48 \mathrm{hr}$ after withdrawal $(233.7 \pm 15.2 \mathrm{nCi} / \mathrm{gm} ; p<0.01$ vs alprazolam and 24 hr withdrawal).

As with $\mathrm{CRF}_{1}$ mRNA expression/binding above, $\mathrm{CRF}_{2 \mathrm{~A}}$ binding in the LS was qualitatively similar, but of smaller magnitude than the changes observed in mRNA expression. Chronic alprazolam treatment induced an increase in $\mathrm{CRF}_{2 \mathrm{~A}}$ receptor binding that did not achieve statistical significance (Fig. $7 B)(676.5 \pm 29.3$ vs $755.2 \pm 58.5 \mathrm{nCi} / \mathrm{gm})$. After withdrawal of alprazolam from the diet, $\mathrm{CRF}_{2 \mathrm{~A}}$ receptor binding decreases to control levels. Within the $\mathrm{VMH}$, although there were no differences in $\mathrm{CRF}_{2 \mathrm{~A}}$ receptor binding as a result of chronic alprazolam administration $(263.9 \pm 16.7$ vs $278.4 \pm 8.7 \mathrm{nCi} / \mathrm{gm}), \mathrm{CRF}_{2 \mathrm{~A}}$ receptor binding was decreased at each withdrawal time point thereafter $(222.5 \pm$ 17.6, $219.9 \pm 12.1$, and $234.4 \pm 13.2 \mathrm{nCi} / \mathrm{gm} ; p<0.05$ vs alprazolam). Because the relative levels of $\mathrm{CRF}_{2 \mathrm{~A}}$ receptor binding in the VMH were not well correlated with mRNA expression during withdrawal, it is unclear whether this decrease reflects a true effect of withdrawal on $\mathrm{CRF}_{2 \mathrm{~A}}$ receptor availability in this region.

\section{Discussion}

Spontaneous withdrawal from alprazolam was associated with marked HPA axis activation, as well as a substantial decrease in food intake and body weight. These effects were maximal at 24-48 hr after withdrawal, and thereafter began to return to control levels. In addition, there was a reversal of the suppression

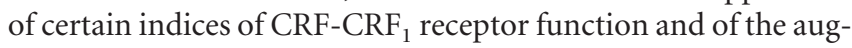
mentation of urocortin $\mathrm{I}-\mathrm{CRF}_{2 \mathrm{~A}}$ receptor function that was induced by chronic alprazolam administration, and previously proposed by our group to plausibly represent an important mechanism in the long-term anxiolytic activity of alprazolam. Surprisingly, the most profound withdrawal-induced alteration in CRF neuronal activity was a robust increase in CRF mRNA expression, from the minimal levels detected in both the control and chronic alprazolam-treated rats, which was demonstrated throughout the frontal, parietal, and temporal cerebral cortex.

As expected from our previous studies, elevated blood concentrations of ACTH and corticosterone revealed that the HPA axis was activated as a consequence of the stressful nature of benzodiazepine withdrawal (Fig. 2). Similar results have been reported after cocaine, ethanol, and morphine withdrawal, demonstrating that activation of the endocrine stress response is a common property of withdrawal from drugs that produce dependence (Keith et al., 1983; Roberts et al., 1992; Milanes et al., 1998). This HPA axis activation was maximal at $24-48 \mathrm{hr}$ after withdrawal and thereafter declined toward baseline levels. It is likely that the increase in HPA axis activity was driven by increased release of hypothalamic CRF, as indicated by the downregulation of anterior pituitary $\mathrm{CRF}_{1}$ receptors at the same time points (Fig. 3). Previous studies (Owens et al., 1989; Skelton et al., 2000b) also demonstrated that ACTH and corticosterone concentrations are reduced during chronic alprazolam administration (Roy-Byrne et al., 1991). The elevated HPA axis activity exhibited during alprazolam withdrawal may represent not only the endocrine stress response to drug withdrawal but also a rebound increase in HPA axis activity after removal of the suppressing influence of chronic benzodiazepine administration.

Similarly, CRF mRNA expression in the PVN, at the head of the HPA axis, increases until $48 \mathrm{hr}$ after alprazolam withdrawal. As is commonly found within the CRF literature, stressors will provoke both increases in CRF mRNA expression in the PVN and corticosterone release from the adrenal cortex, both of which will then subsequently decline toward control levels. There is always a balance between those factors that promote increases in CRF mRNA expression in the PVN (i.e., the stress associated with drug withdrawal) and those that exert negative feedback on this expression (i.e., corticosterone). It is likely that corticosteronemediated negative feedback played a role in the delayed return to baseline of CRF mRNA expression in this region. A factor that may be promoting the prolonged increase in CRF mRNA expression is the action of CRF itself, which has been demonstrated to increase the transcription of its own mRNA in the PVN through a $\mathrm{CRF}_{1}$ receptor-dependent mechanism and is released in elevated quantities during acute withdrawal from several drugs of abuse (Pich et al., 1995; Rodriguez de Fonseca et al., 1997; Richter and Weiss, 1999).

On a time course similar to that of the HPA axis activation, a dramatic increase in CRF mRNA was observed in the frontal, parietal, and temporal cerebral cortex (Fig. 4B). CRF immunoreactivity is localized almost exclusively to a population of GABAergic interneurons found primarily in layers II and III, with some immunoreactivity also located in the deeper cortical layers (Yan et al., 1998). Likewise, it appears that this increase in CRF mRNA expression is caused by a significant increase in the number of neurons actively transcribing CRF (Fig. 4C). Because $\mathrm{CRF}_{1}$ receptor mRNA and binding are decreased by $<20 \%$ from control levels, at a time when cortical CRF mRNA expression was increased by $\sim 300 \%$, this should result in a robust increase in net CRFergic neurotransmission in the cortex during the acute phase of alprazolam withdrawal, although direct measurement of cortical CRF release is not feasible. The time course of this activation of cortical CRF mRNA expression parallels the peak symptomatic severity of alprazolam withdrawal, as manifest by HPA axis activity, anorexia, and weight loss, which has been demonstrated to correlate well with the overall severity of the benzodiazepine 

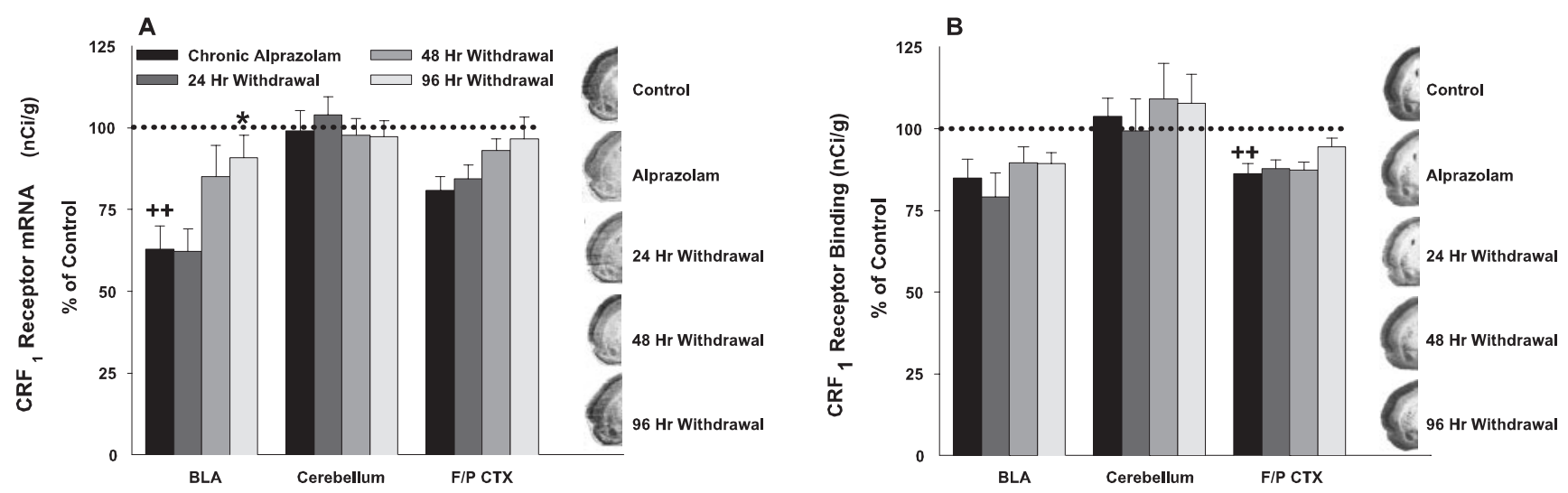

Figure 6. Alterations in $\mathrm{CRF}_{1}$ receptor mRNA expression and receptor binding as a result of chronic alprazolam treatment and after spontaneous alprazolam withdrawal. Each bar represents mean $\pm S E M ; n=6$ per group. $A, C_{1} F_{1}$ receptor $m R N A$ in the BLA and F/P CTX is decreased by chronic alprazolam treatment and during the early stages of spontaneous alprazolam withdrawal. CRF 1 receptor mRNA expression was measured via densitometric analysis subsequent to in situ hybridization performed in $20 \mu \mathrm{m}$ brain slices from male Sprague Dawley rats after $14 \mathrm{~d}$ of a control liquid diet, an alprazolam-supplemented diet at a dose of $90 \mathrm{mg} \cdot \mathrm{kg}^{-1} \cdot \mathrm{d}^{-1}$, and 24,48 , or $96 \mathrm{hr}$ after withdrawal of alprazolam from the diet. ${ }^{++} p<0.01$ versus controls by a two-tailed $t$ test; ${ }^{*} p=$ 0.05 versus chronic alprazolam, and $p=0.07$ versus $24 \mathrm{hr}$ withdrawal groups by one-way ANOVA followed by Student-Newman-Keuls post hoc pairwise analysis. Representative images of CRF 1 receptor mRNA in the cortex and BLA after in situ hybridization are included as an inset to the graph. $B_{1}$ CRF, receptor binding is decreased in the F/P CTX as a result of chronic alprazolam treatment. $\mathrm{CRF}_{1}$ receptor binding was measured via densitometric analysis subsequent to autoradiography performed in $20 \mu \mathrm{m}$ brain slices from male Sprague Dawley rats after $14 \mathrm{~d}$ of a control liquid diet, an alprazolam-supplemented diet at a dose of $90 \mathrm{mg} \cdot \mathrm{kg}^{-1} \cdot \mathrm{d}^{-1}$, and 24,48 , or $96 \mathrm{hr}$ after withdrawal of alprazolam from the diet. ${ }^{++} p<0.01$ versus controls by two-tailed $t$ test. Representative images of $\mathrm{CRF}_{1}$ receptor binding in the cortex and BLA after receptor autoradiography are included as an inset to the graph.
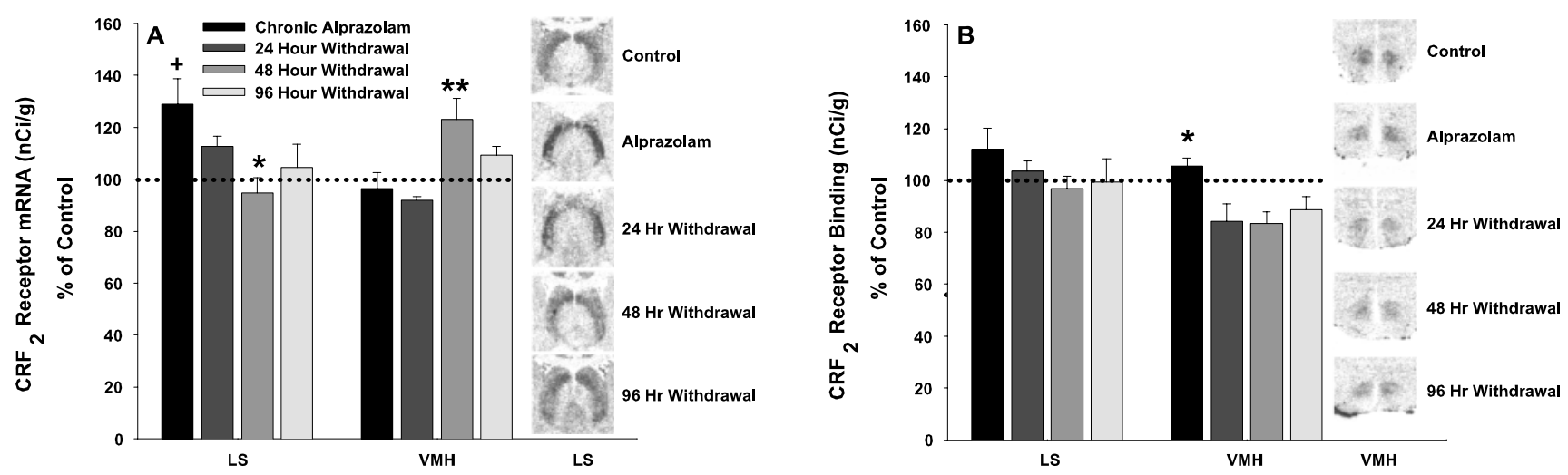

Figure 7. Alterations in $\mathrm{CRF}_{2 \mathrm{~A}}$ receptor $\mathrm{mRNA}$ expression and receptor binding as a result of chronic alprazolam treatment and after spontaneous alprazolam withdrawal. Each bar represents mean $\pm S E M ; n=6$ per group. $A, C R F_{2 A}$ receptor $m R N A$ in the $L S$ is increased as a result of chronic alprazolam treatment and subsequently declines to control levels after alprazolam withdrawal. $\mathrm{CRF}_{2 \mathrm{~A}}$ receptor $\mathrm{mRNA}$ in the VMH is significantly increased at $48 \mathrm{hr}$ after spontaneous alprazolam withdrawal. $\mathrm{CRF}_{2 \mathrm{~A}}$ receptor $\mathrm{mRNA}$ expression was measured via densitometric analysis subsequent to in situ hybridization performed in $20 \mu \mathrm{m}$ brain slices from male Sprague Dawley rats after $14 \mathrm{~d}$ of a control liquid diet, an alprazolam-supplemented diet at a dose of $90 \mathrm{mg} \cdot \mathrm{kg}{ }^{-1} \cdot \mathrm{d}^{-1}$, and 24,48 , or $96 \mathrm{hr}$ after withdrawal of alprazolam from the diet. ${ }^{+} p<0.05$ versus controls by two-tailed $t$ test. ${ }^{*} p<0.05$ versus alprazolam; ${ }^{* *} p<0.01$ versus alprazolam and $24 \mathrm{hr}$ withdrawal by one-way ANOVA followed by Student-Newman-Keuls post hoc pairwise analysis. Representative images of $\mathrm{CRF}_{2 \mathrm{~A}} \mathrm{mRNA}$ in the $L S$ after in situ hybridization are included as an inset to the graph. $B$, $\mathrm{CRF}_{2}$ receptor binding decreases in the $\mathrm{VMH}$ after spontaneous alprazolam withdrawal. $\mathrm{CRF}_{2}$ receptor binding was measured via densitometric analysis subsequent to autoradiography performed in $20 \mu \mathrm{m}$ brain slices from male Sprague Dawley rats after $14 \mathrm{~d}$ of a control liquid diet, an alprazolam-supplemented diet at a dose of $90 \mathrm{mg} \cdot \mathrm{kg}^{-1} \cdot \mathrm{d}^{-1}$, and 24,48 , or $96 \mathrm{hr}$ after withdrawal of alprazolam from the diet. ${ }^{*} p<0.05$ versus all withdrawal time points by one-way ANOVA followed by Student-Newman-Keuls post hoc pairwise analysis. Representative images of CRF ${ }_{2}$ receptor binding in the VMH after receptor autoradiography are included as an inset to the graph. Because the autoradiographic images after in situ hybridization and receptor autoradiography appear fairly similar, only the region that showed the more statistically significant changes was displayed as an inset for $A$ and $B$.

withdrawal syndrome, including other motoric and autonomic symptoms not measured in this experiment (Ryan and Boisse, 1983). Furthermore, the dramatic increase in cortical CRF mRNA expression is very brief in duration, declining to only $60 \%$ above control by $48 \mathrm{hr}$, and to within $10 \%$ of control levels by 96 $\mathrm{hr}$ after withdrawal. Although we are unaware of any prior re- ports of stress-induced or drug-withdrawal-induced increases in cortical CRF mRNA expression, two previous studies have similarly documented increased CRF content in the frontal cortex of rats in a time-dependent manner after cocaine withdrawal (Sarnyai et al., 1995; Zorrilla et al., 2001).

In association with the augmented CRF mRNA expression in 
the cortex, we also observed decreases in cortical $\mathrm{CRF}_{1}$ receptor mRNA and binding, which may represent a receptor downregulation in response to increased ligand availability (Fig. 6). Similar decreases in $\mathrm{CRF}_{1}$ mRNA expression have been demonstrated in the frontal and parietal cortex after precipitated morphine withdrawal (Iredale et al., 2000). Because these changes, indicative of enhanced CRF function in the cerebral cortex, have been demonstrated in response to benzodiazepine, cocaine, and morphine withdrawal, activation of cortical CRF neurons may be a common neurobiological element in withdrawal from drugs of abuse, and as such deserves further study. However, it should be noted that we are unaware of previous data that provides a well established physiological mechanism for these cortical neurons to function as mediators of physical drug withdrawal.

In other studies of several drugs that produce physiological dependence, CRF neuronal systems have consistently been demonstrated to be activated as a result of withdrawal. There is evidence of HPA axis activation, increased CRF concentrations in the CSF, and increased CRF mRNA expression and peptide release in the amygdala temporally correlated with the disappearance of the drug from the blood during withdrawal from cannabis, cocaine, and ethanol (Pich et al., 1995; Rodriguez de Fonseca et al., 1997; Richter and Weiss, 1999; Zorrilla et al., 2001; Maj et al., 2003; Zhou et al., 2003). In fact, CRF concentrations in the amygdala remain elevated throughout the time during which the symptomatic, behavioral indices of the withdrawal syndromes are prominent.

If increased activity in amygdalar CRF neuronal systems plays a similar role in the behavioral expression of anxiety and the aversive emotional consequences of benzodiazepine withdrawal, it was expected that we would find elevated levels of CRF mRNA expression during the acute, symptomatic phase of alprazolam withdrawal. However, the trend for CRF mRNA expression in the CeA after withdrawal did not demonstrate an increase above control levels (Fig. 4A). It is unclear whether benzodiazepine withdrawal is qualitatively different from ethanol, cannabis, or cocaine withdrawal, such that increased CRF release within the CeA is not a component of withdrawal from benzodiazepines or whether the increased CRF neuronal activity in the CeA during the acute phase of withdrawal is not associated with an increase in CRF gene transcription of similar magnitude.

The nature of benzodiazepine withdrawal-induced alterations in $\mathrm{CRF}_{2}$ receptor function are less clear. Within the LS, the heightened degree of expression of $\mathrm{CRF}_{2 \mathrm{~A}}$ receptor mRNA returned to control levels once alprazolam was removed from the diet, and was not significantly altered by withdrawal. (Fig. 7). A similar increase in $\mathrm{CRF}_{2}$ receptor mRNA was demonstrated in morphine-dependent rats, but not control rats, relative to the levels observed during withdrawal (Iredale et al., 2000).

As in our previous study (Skelton et al., 2000b), expression in the EWN of mRNA for the putative endogenous $\mathrm{CRF}_{2}$ ligand, urocortin I, was demonstrated to more than double as a result of chronic alprazolam administration. It thereafter steadily declined, after the withdrawal of alprazolam from the diet, although it is remained statistically elevated above control levels for 24-48 $\mathrm{hr}$ after the initiation of spontaneous alprazolam withdrawal (Fig. 5). It is interesting that urocortin I mRNA expression is increased during both alprazolam treatment, a state of relative CRF deficiency associated with diminished stress and anxiety, and during the stressful, anxiogenic state present during the acute phase of alprazolam withdrawal. This is similar to findings of increased urocortin I mRNA expression in the EWN in both CRF knock-out mice and after restraint stress (Weninger et al., 2000).
It is possible that urocortin I mRNA expression is increased in the EWN as a compensatory mechanism in response to CRF deficiency, whether produced by alprazolam administration or CRF gene knock-out, whereas stress-induced increases in urocortin I mRNA expression may represent an appropriate strategy to invoke potential urocortin-mediated stress coping mechanisms via activation of $\mathrm{CRF}_{2}$ receptors (Reul and Holsboer, 2002). Much data has accumulated to suggest that administration of urocortin-related peptides and/or activation of $\mathrm{CRF}_{2}$ receptors produces anxiolysis or that conversely, lack of functional $\mathrm{CRF}_{2}$ receptors is associated with excess anxiety (Bale et al., 2000; Kishimoto et al., 2000; Valdez et al., 2002, 2003; Bale and Vale, 2003). However, other conflicting reports indicate that antagonism of $\mathrm{CRF}_{2}$ receptors, particularly within the $\mathrm{LS}$, reduces anxiety, suggesting that $\mathrm{CRF}_{2}$ receptors may, in certain sites and circumstances, be involved in the behavioral expression of anxiety, as well (Ho et al., 2001; Takahashi et al., 2001; Bakshi et al., 2002; Pelleymounter et al., 2002).

In addition to its putative role in stress-coping behavior, urocortin I has been established to be a potent anorectic agent through actions mediated specifically at the $\mathrm{CRF}_{2 \mathrm{~A}}$ receptor (Smagin et al., 1998). In this study, we observed a significant weight loss and suppression of food intake that was maximal $24-48 \mathrm{hr}$ after the initiation of alprazolam withdrawal and thereafter returned toward control levels. Because the temporal pattern of these alterations in appetitive behavior were correlated with the time course of urocortin I mRNA elevation in the EWN during withdrawal, it is plausible that urocortin I was the causative agent of these symptoms. Although this is the first study we are aware of to examine indices of urocortin I neuronal function during drug withdrawal, diminished food intake and an accompanying weight loss are core components of the withdrawal syndrome from a variety of drugs that produce physiological dependence (Gellert and Holtzman, 1978; Boisse et al., 1990; Goudie et al., 1993), suggesting that activation of urocortin I-CRF 2 neuronal systems may be a common neurobiological element invoked during drug withdrawal. However, it should be noted that corticosterone concentrations were also elevated over this same time period after withdrawal, and may have also played a causative role in the noted anorexia, because high dose corticosterone is consistently associated with diminished food intake and weight loss in the rat.

In summary, after removal of alprazolam from the diet after chronic administration, most indices of CRF-CRF F $_{1}$ and urocortin $\mathrm{I}_{-} \mathrm{CRF}_{2 \mathrm{~A}}$ function return to their baseline levels over the course of $\sim 96 \mathrm{hr}$. However, the increased expression of CRF mRNA found in the cerebral cortex does not represent merely a return to the original levels present before alprazolam administration, but is instead dramatically elevated above control levels throughout the duration of peak alprazolam withdrawal severity. The physiological significance of this increase, as well as how far it generalizes to withdrawal from other drugs of dependence is still unclear, but such a profound increase in CRFergic neurotransmission is likely to play a functional role in benzodiazepine withdrawal.

\section{References}

Adinoff B, Anton R, Linnoila M, Guidotti A, Nemeroff CB, Bissette G (1996) Cerebrospinal fluid concentrations of corticotropin-releasing hormone $(\mathrm{CRH})$ and diazepam-binding inhibitor (DBI) during alcohol withdrawal and abstinence. Neuropsychopharmacology 15:288-295.

Bakshi VP, Smith-Roe S, Newman SM, Grigoriadis DE, Kalin NH (2002) Reduction of stress-induced behavior by antagonism of corticotropin- 
releasing hormone $2(\mathrm{CRH} 2)$ receptors in lateral septum or CRH1 receptors in amygdala. J Neurosci 22:2926-2935.

Bale TL, Vale WW (2003) Increased depression-like behaviors in corticotropin-releasing factor receptor-2-deficient mice: sexually dichotomous responses. J Neurosci 23:5295-5301.

Bale TL, Smith GW, Contarino A, Chan R, Gold L, Sawchenko PE, Koob GF, Vale WW, Lee K-F (2000) Corticotropin releasing factor receptor 2-deficient mice display anxiety-like behavior and are hypersensitive to stress. Nat Genet 24:410-414.

Ballenger JC (1991) Long-term pharmacologic treatment of panic disorder. J Clin Psychiatry 52:18-23.

Boisse NR, Quaglietta N, Samoriski GM, Guarino JJ (1990) Tolerance and physical dependence to a short-acting benzodiazepine, midazolam. J Pharmacol Exp Ther 252:1125-1133.

Britton K, Morgan J, Rivier J, Vale W, Koob GF (1985) Chlordiazepoxide attenuates CRF-induced response suppression in the conflict test. Psychopharmacology 86:170-174.

Cowley DS, Roy-Byrne PP, Radant A, Ritchie JC, Greenblatt DJ, Nemeroff CB, Hommer DW (1995) Benzodiazepine sensitivity in panic disorder: effects chronic alprazolam treatment. Neuropsychopharmacology 12:147-157.

De Souza EB, Insel TR, Perrin MH, Rivier J, Vale WW, Kuhar MJ (1985) Corticotropin-releasing factor receptors are widely distibuted within the rat central nervous system: an autoradiographic study. J Neurosci 5:3189-3203.

Dunn AJ, File SE (1987) Corticotropin-releasing factor has an anxiogenic action in the social interaction test. Horm Behav 21:193-202.

Gellert VF, Holtzman SG (1978) Development and maintenance of morphine tolerance and dependence in the rat by scheduled access to morphine drinking solutions. J Pharmacol Exp Ther 205:536-546.

Goudie AJ, Harrison AA, Leathley MJ (1993) Evidence for a dissociation between benzodiazepine withdrawal signs. NeuroReport 4:295-298.

Ho SP, Takahashi LK, Livanov V, Spencer K, Lesher T, Maciag C, Smith MA, Rohrbach KW, Hartig PR, Arneric SP (2001) Attenuation of fear conditioning by antisense inhibition of brain corticotropin releasing factor-2 receptor. Brain Res Mol Brain Res 89:29-40.

Imaki T, Wang XQ, Shibasaki T, Harada S, Chikada N, Takahashi C, Naruse M, Demura H (1995) Chlordiazepoxide attenuates stress-induced activation of neurons, corticotropin-releasing factor (CRF) gene transcription and CRF biosynthesis in the paraventricular nucleus (PVN). Mol Brain Res 32:261-270.

Iredale PA, Alvaro JD, Lee Y, Terwilliger R, Chen YL, Duman RS (2000) Role of corticotropin-releasing factor receptor-1 in opiate withdrawal. J Neurochem 74:199-208.

Kalogeras KT, Calogero AE, Kuribayiashi T, Kahn J, Gallucci WT, Kling MA, Chrousos GP, Gold PW (1990) In vitro and in vivo effects of the triazolobenzodiazepine alprazolam on hypothalamic-pituitary-adrenal function: pharmacological and clinical implications. J Clin Endocrinol Metab 70:1462-1471.

Keith LD, Crabbe JC, Robertson LM, Young ER (1983) Ethanol dependence and the pituitary adrenal axis in mice. II. Temporal analysis of dependence and withdrawal. Life Sci 33:1889-1897.

Kishimoto T, Radulovic J, Radulovic M, Lin CR, Schrick C, Hooshmand F, Hermanson O, Rosenfeld MG, Spiess J (2000) Deletion of Crhr2 reveals an anxiolytic role for corticotropin-releasing hormone receptor-2. Nat Genet 24:415-419.

Krulik R, Cerny M (1971) Effects of chlordiazepoxide on stress in rats. Life Sci 10:145-151.

Lewis K, Li C, Perrin MH, Blount A, Kunitake K, Donaldson C, Vaughan J, Reyes TM, Gulyas J, Fischer W, Bilezikjian L, Rivier J, Sawchenko PE, Vale WW (2001) Identification of urocortin III, an additional member of the corticotropin-releasing factor (CRF) family with high affinity for the CRF2 receptor. Proc Natl Acad Sci USA 98:7570-7575.

Li C, Vaughan J, Sawchenko PE, Vale WW (2002) Urocortin IIIimmunoreactive projections in rat brain: partial overlap with sites of type 2 corticotrophin-releasing factor receptor expression. J Neurosci 22:991-1001.

Lowry OH, Rosebrough NJ, Farr AL, Randall RJ (1951) Protein measurement with the Folin phenol reagent. J Biol Chem 193:265-275.

Maj M, Turchan J, Smialowska M, Przewlocka B (2003) Morphine and cocaine influence on CRF biosynthesis in the rat central nucleus of amygdala. Neuropeptides 37:105-110.
Milanes MV, Laorden ML, Chapleur-Chateau M, Burlet A (1998) Alterations in corticotropin-releasing factor and vasopressin content in rat brain during morphine withdrawal: correlation with hypothalamic noradrenergic activity and pituitary-adrenal response. J Pharmacol Exp Ther 285:700-706

Miller NS (1997) Benzodiazepines: behavioral and pharmacologic basis of addiction, tolerance, and dependence. Essent Psychopharmacol 2:119-145.

Muller MB, Zimmermann S, Sillaber I, Hagemeyer TP, Deussing JM, Timpl P, Kormann MS, Droste SK, Kuhn R, Reul JM, Holsboer F, Wurst W (2003) Limbic corticotropin-releasing hormone receptor 1 mediates anxiety-related behavior and hormonal adaptation to stress. Nat Neurosci 6:1100-1107.

Owens MJ, Nemeroff CB (1991) Physiology and pharmacology of corticotropin-releasing factor. Pharmacol Rev 43:425-473.

Owens MJ, Bissette G, Nemeroff CB (1989) Acute effects of alprazolam and adinazolam on the concentrations of corticotropin-releasing factor in the rat brain. Synapse 4:196-202.

Owens MJ, Vargas MA, Knight DL, Nemeroff CB (1991) The effects of alprazolam on corticotropin-releasing factor neurons in the rat brain: acute time course, chronic treatment and abrupt withdrawal. J Pharmacol Exp Ther 258:349-356.

Paxinos G, Watson C (1986) The rat brain in stereotaxic coordinates. San Diego: Harcourt Brace Jovanovich.

Pelleymounter MA, Joppa M, Ling N, Foster AC (2002) Pharmacological evidence supporting a role for central corticotropin-releasing factor(2) receptors in behavioral, but not endocrine, response to environmental stress. J Pharmacol Exp Ther 302:145-152.

Pich EM, Lorang M, Yeganeh M, Rodriguez de Fonseca F, Raber J, Koob GF, Weiss F (1995) Increase of extracellular corticotropin-releasing factorlike immunoreactivity levels in the amygdala of awake rats during restraint stress and ethanol withdrawal as measured by microdialysis. J Neurosci 15:5439-5447.

Primus RJ, Yevich E, Baltazar C, Gallager DW (1997) Autoradiographic localization of $\mathrm{CRF}_{1}$ and $\mathrm{CRF}_{2}$ binding sites in adult rat brain. Neuropsychopharmacology 17:308-316.

Reul JM, Holsboer F (2002) Corticotropin-releasing factor receptors 1 and 2 in anxiety and depression. Curr Opin Pharmacol 2:23-33.

Reyes TM, Lewis K, Perrin MH, Kunitake KS, Vaughan J, Arias CA, Hogenesch JB, Gulyas J, Rivier J, Vale WW, Sawchenko PE (2001) Urocortin II: a member of the corticotropin-releasing factor (CRF) neuropeptide family that is selectively bound by type 2 CRF receptors. Proc Natl Acad Sci USA 98:2843-2848.

Richter RM, Weiss F (1999) In vivo CRF release in rat amygdala is increased during cocaine withdrawal in self-administering rats. Synapse 32:254-261.

Roberts AJ, Crabbe JC, Keith LD (1992) Genetic differences in hypothalamic-pituitary-adrenal axis responsiveness to acute ethanol and acute ethanol withdrawal. Brain Res 579:296-302.

Rodriguez de Fonseca F, Carrera MRA, Navarro M, Koob GF, Weiss F (1997) Activation of corticotropin-releasing factor in the limbic system during cannabinoid withdrawal. Science 276:2050-2054.

Rohrer T, Von Richthofen V, Schulz C, Beyer J, Lehnert H (1994) The stress-, but not corticotropin-releasing hormone-induced activation of the pituitary-adrenal axis in man is blocked by alprazolam. Horm Metab Res 26:200-206.

Romach MK, Somer GR, Sobell LC, Sobell MB, Kaplan HL (1992) Characteristics of long-term alprazolam users in the community. J Clin Psychopharmacol 12:316-332.

Roy-Byrne PP, Cowley DS, Hommer D, Ritchie J, Greenblatt D, Nemeroff C (1991) Neuroendocrine effects of diazepam in panic and generalized anxiety disorders. Biol Psychiatry 30:73-80.

Ryan GP, Boisse NR (1983) Experimental induction of benzodiazepine tolerance and physical dependence. J Pharmacol Exp Ther 226:100-107.

Sarnyai Z, Biro E, Gardi J, Vecsernyes M, Julesz J, Telegdy G (1995) Brain corticotropin-releasing factor mediates "anxiety-like" behavior induced by cocaine withdrawal in rats. Brain Res 675:89-97.

Simmons DM, Arriza JL, Swanson LW (1989) A complete protocol for in situ hybridization of messenger RNAs in brain and other tissues with radiolabeled single-stranded RNA probes. J Histotechnol 12:169-181.

Skelton KH, Owens MJ, Nemeroff CB (2000a) The neurobiology of urocortin. Regul Pept 93:85-92. 
Skelton KH, Nemeroff CB, Knight DL, Owens MJ (2000b) Chronic administration of the triazolobenzodiazepine alprazolam produces opposite effects on corticotropin-releasing factor and urocortin neuronal systems. J Neurosci 20:1240-1248.

Skelton KH, Nemeroff CB, Owens MJ (2000c) A comparison of plasma alprazolam concentrations following different routes of chronic administration in the Sprague-Dawley rat: implications for psychotropic drug research. Psychopharmacology 151:72-76.

Smagin GN, Dunn AJ (2000) The role of CRF receptor subtypes in stressinduced behavioural responses. Eur J Pharmacol 405:199-206.

Smagin G, Howell L, Ryan D, De Souza E, Harris R (1998) The role of $\mathrm{CRH}_{2}$ receptors in corticotropin-releasing factor- and urocortin-induced anorexia. NeuroReport 9:1601-1606.

Spina M, Merlo-Pich E, Chan RKW, Basso AM, Rivier J, Vale W, Koob GF (1996) Appetite-suppressing effects of urocortin, a CRF-related neuropeptide. Science 273:1561-1564.

Swerdlow NR, Geyer MA, Vale WW, Koob GF (1986) Corticotropin releasing factor potentiates acoustic startle in rats: blockade by chlordiazepoxide. Psychopharmacology 88:147-152.

Takahashi LK, Ho SP, Livanov V, Graciani N, Arneric SP (2001) Antagonism of CRF(2) receptors produces anxiolytic behavior in animal models of anxiety. Brain Res 902:135-142.
Valdez GR, Inoue K, Koob GF, Rivier J, Vale W, Zorrilla EP (2002) Human urocortin II: mild locomotor suppressive and delayed anxiolytic-like effects of a novel corticotropin-releasing factor related peptide. Brain Res 943:142-150.

Valdez GR, Zorrilla EP, Rivier J, Vale WW, Koob GF (2003) Locomotor suppressive and anxiolytic-like effects of urocortin 3, a highly selective type 2 corticotropin-releasing factor agonist. Brain Res 980:206-212.

Weninger SC, Peters LL, Majzoub JA (2000) Urocortin expression in the Edinger-Westphal nucleus is up-regulated by stress and corticotropinreleasing hormone deficiency. Endocrinology 141:256-263.

Yan XX, Baram TZ, Gerth A, Schultz L, Ribak CE (1998) Co-localization of corticotropin-releasing hormone with glutamate decarboxylase and calcium-binding proteins in infant rat neocortical interneurons. Exp Brain Res 123:334-340.

Zhou Y, Spangler R, Ho A, Kreek MJ (2003) Increased CRH mRNA levels in the rat amygdala during short-term withdrawal from chronic "binge" cocaine. Brain Res Mol Brain Res 114:73-79.

Zorrilla EP, Valdez GR, Weiss F (2001) Changes in levels of regional CRF-like-immunoreactivity and plasma corticosterone during protracted drug withdrawal in dependent rats. Psychopharmacology 158: $374-381$. 